\title{
BINUSMAYA SEBAGAI SUMBER MATERI DALAM PEMBELAJARAN BERBASIS E-LEARNING
}

\author{
Suparto Darudiato; Kadek Iran Wibowo \\ Information Systems Department, School of Information Systems, Binus University \\ Jl. K.H. Syahdan No. 9, Palmerah, Jakarta Barat 11480 \\ supartod@binus.edu; Kadek.pesat@gmail.com
}

\begin{abstract}
E-learning is a media that used in order to help learning process. This paper aims to determine the components that support Binusmaya to become one of e-learning media. It also describes the benefits that can be provided by binusmaya as a learning media. Additionally, this paper analysis the constraints that must be considered in implementing Binusmaya so that it can give benefit optimally. Data and information used in this paper are obtained from several books, website, journal and questionnaires related with topic. The result from this paper is expected to provide information and knowledge about binusmaya as a learning media based elearning.
\end{abstract}

Keyword: e-learning, Binusmaya, learning media

\begin{abstract}
ABSTRAK
E-learning adalah salah satu metode yang digunakan dalam membantu proses belajar mengajar. Penulisan ini bertujuan untuk mengetahui komponen-komponen apa saja yang mendukung Binusmaya sehingga menjadi salah satu media belajar yang berbasis e-learning serta menggambarkan manfaat apa saja yang diberikan oleh Binusmaya sebagai media belajar berbasis e-learning. Selain itu, paper ini juga menganalisis kendala-kendala yang harus diperhatikan dalam penerapan Binusmaya sebagai media belajar berbasis elearning agar dapat bermanfaat dengan baik. Data dan informasi yang digunakan dalam penulisan ini diperoleh dari beberapa buku, website, jurnal dan kuesioner yang berkaitan dengan topik. Hasil pembahasan dalam penulisan ini diharapkan dapat memberikan informasi dan pengetahuan tentang Binusmaya sebagai media belajar yang berbasis e-learning.
\end{abstract}

Kata kunci: e-learning, Binusmaya, media belajar 


\section{PENDAHULUAN}

Sumber daya manusia menjadi hal yang penting dalam suatu proses pembanguna. Sumber daya manusia juga menjadi salah satu sasaran dalam pembangunan saat ini. Dengan sangat pentingnya sumber daya manusia, tentu perlu diperhatikan juga bagaimana kualitas dari sumber daya manusia itu sendiri. Seperti yang dikatakan Husna (2008) melalui pendidikanlah sumber daya manusia bisa ditingkatkan kualitasnya, oleh karena itu model pembelajaran dalam dunia pendidikan harus dikembangkan. Dibutuhkan suatu cara yang bisa mendukung proses penyampaian materi dengan baik. Perkembangan teknologi yang semakin berkembang bisa dimanfaatkan untuk membantu perbaikan kualitas pendidikan yang ada saat ini. Ada beberapa cara yang bisa digunakan untuk membantu meningkatkan kualitas pendidikkan yang ada, salah satunya adalah dengan penggunaan e-learning dalam proses pembelajaran.

Seperti yang dikatakan oleh Effendi \& Hartono (2005) e-learning adalah kegiatan pendidikan yang di mana dalam proses pembelajarannya menggunakan fasilitas komputer dan internet. e-learning sendiri bisa berfungsi baik dan sesuai dengan tujuannya apabila sarana dan prasarana yang digunakan memadai. Tidak hanya sebatas itu saja, tentu dukungan dari para pengguna e-learning juga mempengaruhi keberhasilan penggunaan metode ini.

Menurut Harahap (2008) e-learning dapat dipandang sebagai suatu cara yang inovatif yang bisa digunakan untuk menjadi media penyampaian yang baik, dalam hal ini penyampaian di dalam bidang pendidikan. Berdasarkan penelitian yang dilakukan Hasbullah \& Somantri (2009), kecenderungan pengembangan $e$-learning sebagai salah satu alternatif pembelajaran diberbagai tingkat pendidikan terutama diperguruan tinggi terjadi seiring dengan perkembangan dibidang teknologi dan informasi saat ini. Dengan kata lain, perkembangan teknologi dan informasi bisa menciptakan suatu cara yang bisa digunakan untuk mengembangkan suatu hal baru dalam hal ini adalah dunia pendidikan.

Sebuah portal e-learning terdiri dari beberapa object, object-object yang terdapat didalam elearning disebut dengan learning object, yang di mana learing object ini menyusun isi secara keseluruhan apa yang ada dialam sebuah media e-learning seperti isi dan tampilannya. Seperti yang dikatakan Barritt \& Alderman (2004) learning object merupakan elemen yang ada didalam sebuah media digital (text, gambar, video, audio, dan lainnya) yang ditempatkan secara bersamaan. Dengan adanya learning object ini, sebuah media e-learning akan menjadi lebih menarik dalam penggunaannya.

Salah satu portal e-learning adalah Binusmaya. Binusmaya digunakan untuk membantu mahasiswa Universitas Bina Nusantara dalam memperoleh materi pembelajaran yang diperlukan dalam proses belajar dalam perkuliahan. Binusmaya mempermudah mahasiswa untuk melakukan proses belajar karena bisa diakses oleh semua mahasiswa kapan saja dan di mana saja, selama ada koneksi internet dan komputer sebagai sarana penunjang Binusmaya. Seperti yang diakatakan oleh Clark \& Mayer (2008), dalam e-learning, proses pendistribusian pembelajaran dilakukan melalui komputer di mana komputer tersebut memiliki koneksi internet atau pun ekstranet sehingga bisa saling menghubungkan satu sama lain.

Saat ini Binusmaya tidak hanya berfungsi sebagai media pembelajaran semata, tetapi juga sebagai sumber informasi yang dibutuhkan oleh mahasiswa selama menempuh pendidikan di universitas Bina Nusantara. Tetapi, perlu dicermati dan diteliti lebih mendalam, apakah Binusmaya benar-benar sudah dijadikan media pembelajaran? Seperti yang dikatakan oleh Harahap (2008), untuk menjadikan sistem e-learning lebih bermanfaat dan menjadi lebih fungsional, harus dilakukan integrasi yang disesuaikan dengan perancangan materi, bahan pelajaran, dan konten. Bukan hanya 
komponen yang harus diperhatikan dalam membangun sebuha e-learning, tetapi ada prinsip-psrinsip yang juga harus diperhatikan. Menurut Clark \& Mayer (2003) penerapan e-learning yang baik harus bisa memperhatikan beberapa prinsip yang ada seperti: multimedia, modality, redudansi, personalisasi, dan coherence. Komponen dan prinsip akan menjadi dasar dibangunnya sebuah e-learning yang baik.

\section{METODE}

Pengumpulan data dan informasi yang terkait dengan penelitian dilakukan melalui pendekatan studi pustaka, di mana data dan informasi yang digunakan didapat atau diperoleh melalui beberapa sumber buku, web site, dan beberapa jurnal yang terkait dengan penulisan ini.

\section{HASIL DAN PEMBAHASAN}

Seperti halnya pendefinisian tentang e-learning, pengelompokan atau pengkategorian $e$ learning tidak akan dengan mudah bisa dilakukan melihat banyaknya pendapat yang mendasari hal ini. Dalam mengkategorikan sesuatu, tentu ada beberapa hal atau sudut pandang yang membuat pengkategorian tersebut lebih maksimal (Widhiartha, 2008). Dengan adanya pengkategorian yang disesuaikan dengan kebutuhan, diharapkan tidak ada kesalahan penerapan dalam proses belajar mengajar yang berbasis e-learning itu sendiri.

\section{Kategori Pengelompokan Dasar E-Learning}

Ditinjau dari segi interaksi sistem dengan manusia ada tiga kategori pengelompokan dasar terhadap e-learning, yaitu: synchronous learning, self-directed learning, dan asynchronous (collaborative) learning.

\section{Synchronous Learning}

Pada pembelajaran dengan kategori ini proses pembelajaran dilakukan ditempat yang berbeda tetapi dilakukan pada waktu yang bersamaan. Maksudnya adalah, pengajar memberikan materi pelajaran dari tempat yang berbeda dan siswa yang menerimannya juga berada ditempat yang berbeda, tetapi waktunya bersamaan. Metode pembelajaran ini membutuhkan media internet yang baik untuk melakukannya, karena harus melakukan teleconference. Dengan melakukan proses ini, seakan-akan pengajar dan siswa berada ditempat yang sama.

\section{Self-directed Learning}

Sistem pembelajaran ini dilakukan secar mandiri oleh para siswa, mahasiswa mencoba mencari sendiri apa saja materi yang mereka perlukan untuk proses belajar. Dalam kategori ini, tidak ada pengajar yang membimbing siswa untuk mencari materi yang mereka perlukan, tetapi siswa dilatih untuk memaksimalkan kemampuan yang dimiliki dalam menemukan materi yang dibutuhkan.

\section{Asynchronous (collaborative) Learning}

Dalam kategori ini, terjadi perpaduan antara dua kategori sebelumnya. Dalam proses ini siswa belajar secara individu tetapi tetap dapat berkomunikasi dengan siswa-siswa lainnya dan juga dapat berkomunikasi dengan para pengajar walaupun tidak pada waktu yang sama. Kategori ini menggunakan aplikasi dalam penerapannya, seperti sebuah portal yang menjadi tempat mereka 
membagi ilmu dan juga sebagai tempat pengajar menyampaikan materi yang digunakan oleh siswanya dalam proses belajar.

Dari ketiga kategori di atas, tentu masing-masing kategori memiliki kelebihan dan kekurangan. Kelebihan dan kekurangan dari ketiga kategori di atas dapat dilihat dalam Tabel 1 di bawah ini.

Tabel 1 Kelebihan dan Kekurangan dari Tiga Kategori Dasar e-Learning

\begin{tabular}{|c|c|c|}
\hline Kategori & Kelebihan & Kelemahan \\
\hline Synchronous & $\begin{array}{llr}\text { (1) } & \text { Memiliki kesamaan } & \text { dengan } \\
& \text { sistem pembelajaran } & \text { didalam } \\
& \text { kelas } & \\
\text { (2) } & \text { Interaksi secara } & \text { langsung } \\
& \text { dengan pengajar }\end{array}$ & $\begin{array}{l}\text { (1) Harus melakukan pengaturan waktu } \\
\text { (2) Memerlukan biaya untuk } \\
\text { melakukannya } \\
\text { (3) Konektivitas internet harus memadai }\end{array}$ \\
\hline Self-directed & $\begin{array}{l}\text { (3) Proses belajar dapat terjadi di } \\
\text { mana saja } \\
\text { (4) Siswa tidak merasa terpaksa } \\
\text { dalam proses belajarnya }\end{array}$ & $\begin{array}{l}\text { (4) Kurangnya pengawasan dari orang } \\
\text { tua. } \\
\text { (5) Tidak adanya bimbingan yang } \\
\text { diberikan oleh pengajar }\end{array}$ \\
\hline Asynchronous & $\begin{array}{l}\text { (5) Pengajar bisa memberikan } \\
\text { bimbingan bagi para siswanya } \\
\text { (6) Siswa bisa mencari apa yang } \\
\text { mereka butuhkan dalam proses } \\
\text { belajarnya } \\
\text { (7) Memungkinkan proses } \\
\text { pembelajaran secara kolaboratif }\end{array}$ & $\begin{array}{l}\text { (6) Tidak adanya penjadwalan tertentu } \\
\text { (7) Kurang efisiennya waktu. }\end{array}$ \\
\hline
\end{tabular}

Binusmaya (http://binusmaya.binus.ac.id) adalah salah satu portal yang digunakan dalam proses pembelajaran bagi para mahasiswa universitas Bina Nusantara yang berbasis e-learning. Dengan adanya Binusmaya ini, mahasiswa dan dosen akan lebih mudah dalam melakukan proses pembelajaran dan mendapatkan informasi yang dibutuhkan selama berada di universitas Bina Nusantara. Dengan kemudahan yang didapatkan, Binusmaya tidak hanya akan memberikan keuntungan bagi para penggunanya, tetapi memberikan keuntungan tersendiri bagi universitas Bina Nusantara. Tampilan Binusmaya yang digunakan oleh universitas Bina Nusantara sebagai media pembelajaran berbasis E-Learning dapat dilihat pada Gambar 1.

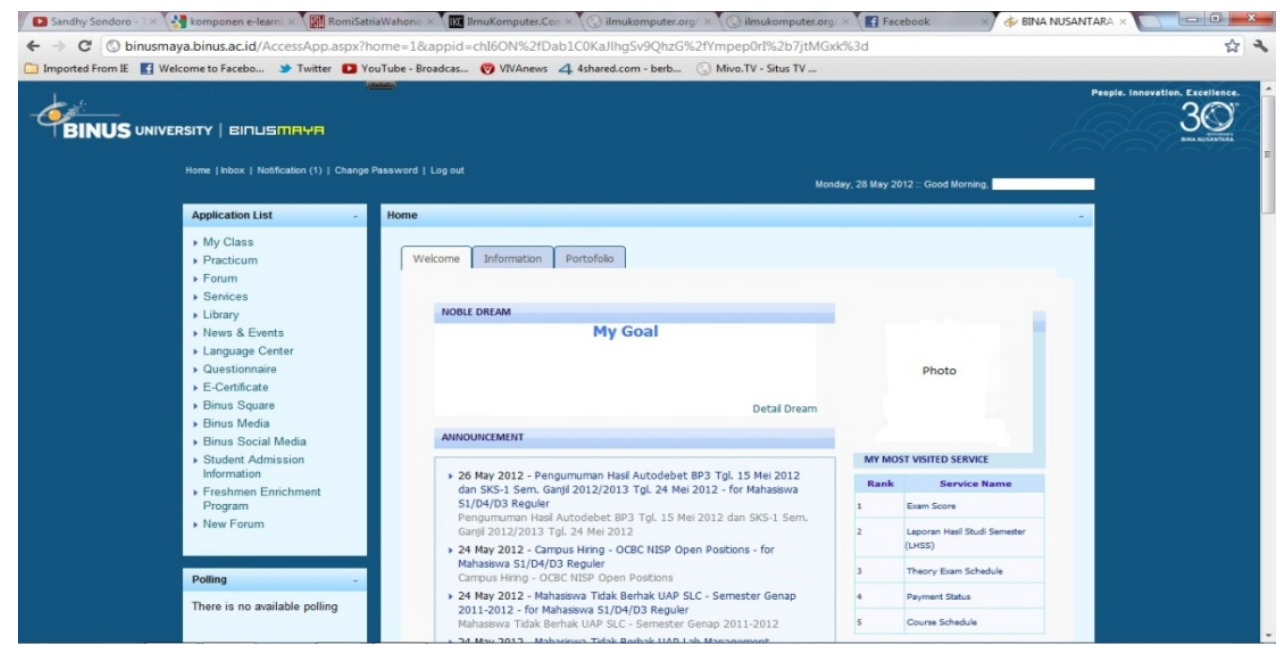

Gambar 1 Binusmaya 


\section{Komponen yang Membentuk Binusmaya}

Menurut Wihono (2008) ada tiga komponen yang ada dalam sebuah e-learning, yaitu $e$ learning system (siswa), e-learning content (isi), infrastructure (admin).

Dalam penerapannya Binusmaya memiliki beberapa komponen yang menjadikan Binusmaya sebagai salah satu media yang digunakan untuk mendukung proses belajar. Komponen ini yang nantinya akan mendukung Binusmaya sebagai salah satu alat pembelajaran, agar pemanfaatan Binusmaya menjadi lebih maksimal, adapun komponen yang mendukung Binusmaya dapat dilihat pada Gambar 2 di bawah ini.

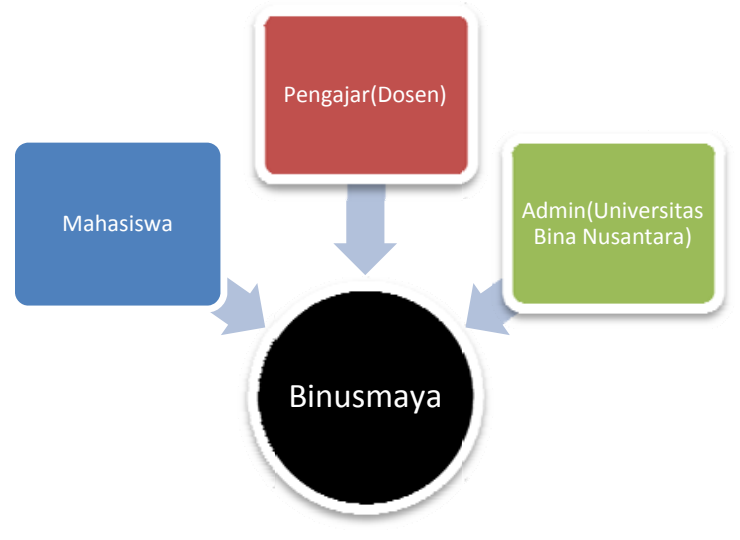

Gambar 2 Komponen yang mendukung binusmaya

Dilihat dari Gambar 2 di atas, ada tiga komponen yang mendukung didalam Binusmaya sebagai e-learning yaitu: mahasiswa, pengajar (dosen), dan admin.

\section{Mahasiswa}

Mungkin pertanyaan yang akan timbul adalah, mengapa mahasiswa menjadi komponen di dalam Binusmya?

Binusmaya merupakan media yang digunakan dalam proses pembelajaran yang diterapkan oleh universitas Bina Nusantara dan pengguna utama dari Binusmaya adalah mahasiswa. Binusmaya bisa digunakan oleh mahasiswa baik itu didalam ataupun diluar kelas, Binusmaya ini dirancang agar mahasiswa tidak hanya mendapatkan materi pembelajaran dari dalam kelas, tetapi saat mereka berada dirumah Binusmaya dapat digunakan untuk mendapatkan materi perkuliahan.

\section{Pengajar(Dosen)}

Pengajar adalah orang yang memberikan pengetahuan dan materi yang mendukung proses belajar mahasiswa. Bisa dikatakan pengajar adalah bagian terpenting dari suatu proses pembelajaran. Oleh sebab itu, pengajar menjadi komponen penting berikutnya yang ada dalam Binusmaya. Dengan Binusmaya pengajar bisa membagi pengetahuan yang mereka miliki dan memberikannya kepada mahasiswa.

Dalam suatu proses penyampaian materi pembelajaran, pengajar bisa langsung memberikan materi yang dipelajari atau menggunakan media dalam memberikan materi kepada mahasiswanya. 
Binusmaya menjadi salah satu media yang digunakan oleh pengajar untuk menyampaikan materi secara tidak langsung, tetapi materi yang diberikan bisa langsung diterima oleh mahasiswanya. Disini juga pengajar bisa menambahkan materi yang tidak diberikan didalam kelas kepada mahasiswanya dengan mudah, tanpa harus menemui mahasiswa secara langsung.

\section{Admin}

Di sini admin adalah orang yang menjaga dan merawat Binusmaya. Maksudnya adalah, admin melakukan pengecekan-pengecekan dan menangani masalah yang terjadi pada Binusmaya. Admin juga menyediakan hardware dan software yang digunakan didalam server Binusmaya. Admin harus bisa menggunakan software dan hardware yang baik, agar dalam proses penggunaan Binusmaya tidak mengalami gangguan yang dapat menimbulkan masalah dalam proses pembelajaran yang dilakukan oleh mahasiswa.

\section{Manfaat yang Diberikan Binusmaya}

Pembangunan sebuah e-learning tentu diharapkan memberikan manfaat bagi semua pihak, bukan hanya dari pihak pengguna saja tetapi dari pihak-pihak lain yang terkait. Seperti halnya Binusmaya, dalam pembangunannya sebagai media e-learning diharapkan mampu memberikan manfaat yang baik bagi mahasiswa dan dosen. Bukan hanya mahasiswa dan dosen, tetapi bagi universitas Bina Nusantara sendiri yang membangun Binusmaya sebagai media belajar yang berbasis e-learning.

\section{Manfaat yang diberikan kepada mahasiswa}

Pertama adalah memudahkan mahasiswa untuk mendapatkan materi perkuliahan. Binusmaya mempunyai peranan penting dalam proses belajar mahasiswanya, dengan bantuan Binusmaya mahasiswa bisa dengan mudah mendapatkan materi perkuliahan yang ada. Ini bertujuan, agar mahasiswa bisa mempelajari materi kuliah sebelum atau sedudah melakukan pertemuan dengan dosen didalam kelas. Dengan Binusmaya, mahasiswa bisa belajar kapan saja baik itu di kampus ataupun diluar kampus.

Kedua, memberikan informasi tentang perkuliahan. Dalam sebuah proses pembelajaran, tentu mahasiswa membutuhkan informasi-informasi yang mendukung perkuliahan seperti jadwal perkuliahan dan yang lainnya. Dengan adanya dukungan informasi yang baik tentang perkuliahan, ini bisa membuat proses belajar mahasiswa menjadi lebih baik dan maksimal. Binusmaya memberikan informasi yang mendukung proses belajar mahasiswanya, dengan menyediakan segala informasi yang berhubungan dengan kegiatan mahasiswa didalam perkuliahannya.

Ketiga, memudahkan komunikasi antara mahasiswa dan dosen. Komunikasi antara mahasiswa dan dosen menjdai hal penting yang dapat mempengaruhi jalannya proses pembelajaran di kelas. Dengan komunikasi yang baik antara mahasiswa dan dosen, dosen akan lebih mudah memberikan dan membantu mahasiswa untuk belajar. Dan sebaliknya, mahasiswa bisa mendapat bimbingan dari dosen pengajarnya dengan baik.

Keempat, mendistribusikan materi perkuliahan dengan cepat. Binusmaya mampu memberikan kemudahan bagi mahasiswa dalam mendapatkan materi kuliah. Tentu tidak itu saja, materi perkuliahan juga disampaikan dengan cepat. Maksudnya adalah, mahasiswa bisa menerima semua materi yang disediakan oleh dosen kapan saja dan dosen juga bisa memberikan materi yang sekiranya perlu dalam proses belajar kapan saja. Semua materi yang diberikan oleh dosen, akan diterima oleh mahasiswa saat itu juga. 


\section{Manfaat yang diberikan kepada dosen}

Dengan Binusmaya dosen bisa dengan mudah memberikan materi perkuliahan yang dibutuhkan oleh mahasiswa. Penyampaian materi ini bisa dilakukan dapan saja, dengan begini dosen tidak perlu menunggu saat berada didalam kelas untuk menyampaikan materi perkuliahan yang dibutuhkan oleh mahasiswa.

\section{Manfaat Bagi Universitas Bina Nusantara}

Binusmaya menjadi salah satu faktor penting dalam peningkatan mutu pendidikan di universitas Bina Nusantara. Dengan adanya Binusmaya proses belajar mahasiswa akan menjadi lebih baik. Ini dikarenakan para mahasiswa akan lebih mudah mendapatkan materi untuk proses belajar mereka. Kemudahan yang didapatkan oleh mahasiswa ini akan bisa berdampak terhadap bagiaman prestasi mereka didalam kelas. Dengan tingginya prestasi yang mereka berikan, ini akan bisa meningkatkan mutu pendidikan yang ada di universitas Bina Nusantara.

\section{Hambatan dalam Penggunaan Binusmaya}

Dalam setiap penerapan suatu sistem, pasti akan menghadapi kendala dalam perjalanannya. Kendala sudah pasti menjadi faktor dalam penerapan suatu metode pembelajaran seperti e-learning. Tidak hanya dalam penerapan e-learning yang mengalami kendala, tetapi dalam setiap penerapan hal yang baru sudah pasti memiliki kendala. Kendala-kendala yang muncul ini tidak hanya terjadi pada awal penerapannya sendiri, tetapi bisa saja kendala ini muncul saat sebuah sistem itu sendiri sudah diterapkan dan dijalankan. Tidak sedikit sistem yang sudah berjalan atau sudah dibangun mengalami kendala yang berat, dan tidak sedikit juga kendala ini dapat menyebabkan kegagalan dari penerapan sistem itu sendiri.

Binusmaya adalah salah satu cara pembelajaran yang berbasis e-learning, tentu dalam penerapannya mengalami kendala. Berdasarkan kuesioner yang disebarkan secara acak kepada dosen dan mahasiswa, maka dapat dikelompokkan beberapa kendala yang terjadi saat Binusmaya diterapkan sebagai salah satu media pembelajaran yang berbasis e-learning. Adapun masalahnya adalah sebagai berikut:

\section{Dosen Kesulitan dalam Menggunakan Binusmaya}

Tidak semua orang bisa menggunakan teknologi yang berkembang saat ini. Walaupun banyak dikatakan sekarang adalah jamannya teknologi, tetapi pada kenyataannya tidaklah seperti itu. Inilah yang terjadi dengan beberapa dosen yang sekarang menggunakan Binusmaya. Pada saat awal pengenalan Binusmaya, banyak dosen yang masih kurang memahami cara penggunaannya. Bahkan mereka merasa tidak bisa menggunakan Binusmaya ini, dan merasa lebih baik menggunakan cara yang sederhana seperti menulis.

\section{Mahasiswa tidak Menggunakan Binusmaya dengan Maksimal}

E-learning bertujuan untuk meningkatkan minat belajar dari para siswanya sendiri dan diharapkan dengan adanya metode e-learning ini siswa akan lebih mudah dalam melakukan proses belajar. Binusmaya dibuat untuk memudahkan para mahasiswa dalam memperoleh materi perkuliahan dan mendukung proses perkuliahan dengan baik. Tetapi, tentu tidak semudah itu untuk melakukannya. Mahasiswa hanya mengakses Binusmaya pada saat mereka ingin menggunakannya, padahal ini bukan merupakan tujuan utama dibuatnya Binusmaya. 


\section{Jumlah Mahasiswa dan Dosen yang Banyak}

Dalam suatu badan pendidikan seperti Universitas, sudah pasti memiliki banyak pengajar dan mahasiswa. Binusmaya dibuat untuk memenuhi kebutuhan dari mahasiswa, dosen, dan universitas Bina Nusantara sendiri. Tetapi bagaimana dengan jumlah orang yang mengaksesnya? Jika pada saat yang bersamaan, semua mahasiswa mengakses dan dosen mengakses Binusmaya. Sudah pasti server utama tidak akan kuat untuk menampung akses data dari sekian banyak user yang mengakses. Tentu masalah ini menjadi penting, karena jika ini terjadi pada saat mahasiswa memerlukan materi yang digunakan untuk proses belajar, mereka tidak bisa mendapatkannya dengan cepat. Ini akan berpengaruh kepada kesiapan mereka sebelum melakukan proses belajar dan mengumpulkan tugas yang diberikan oleh dosen penganjar mereka.

\section{Tampilan Binusmaya Kurang Menarik}

Penampilan akan mempengaruhi kenyamanan user saat mengakses Binusmaya. Jika dari tampilan saja sudah tidak menarik, tentu user akan merasa bosan. Sebaliknya, dengan tampilan menarik, user akan merasa nyaman utuk mengakses Binusmaya itu sendiri.

\section{PENUTUP}

E-learning menjadi salah satu cara yang bisa dilakukan atau digunakan dalam upaya meningkatkan kualitas pendidikan saat ini. Dengan adanya e-learning dalam proses belajar maka proses belajar akan menjadi lebih mudah dan menjadi lebih fleksibel untuk dilakukan. Untuk itu penggunaan e-learning dalam dunia pendidikan harus ditingkatkan, tidak hanya di tingkat Perguruan Tinggi tetapi di jenjang pendidikan yang lain.

Binusmaya begitu penting keberadaanya bagi mahasiswa, dosen, dan universitas Bina Nusantara sendiri. Dengan adanya Binusmaya ini, mahasiswa bisa mempermudah proses belajar dan memudahkan mahasiswa untuk memperoleh informasi yang mendukung perkuliahan di universitas Bina Nusantara.

\section{DAFTAR PUSTAKA}

Barritt, C., \& Alderman Jr, F. L. (2004). Creating a Reusable Learning Object Strategy. San Francisco: Pfeiffer.

Clark, R., \& Mayer, R. E. (2008). E-learning and the Science of Instruction: Proven Guidelines for Consumers and Designers of Multimedia Learning. San Francisco: Preiffer.

Effendi, E., \& Hartono, Z. (2005). E-learning: Konsep dan Aplikasi (edisi 1). Yogyakarta: Andi.

Harahap, H. P. (2008). Membangun sistem e-learning berbasis multimedia. Ekubank, 2.

Hasbullah, \& Somantri, M. (2009). Pengembangan model pembelajaran e-learning untuk meningkatkan kualitas proses dan hasil belajar mahasiawa pada mata kuliah energi dan konversi. Jurnal Penelitian, 2. 
Husna, A. (2008). Kesiapan jurusan teknologi dalam implementasi e-learning. Jurnal Penelitian Pendidikan, 5.

Widhiartha, A. P. (2008, juli 1). Memahami Lebih Lanjut tentang e-Learning. Diakses 11 April 2012 dari http://pandawa.ipb.ac.id/ilmukomputer.org/wpcontent/uploads/2008/07/widhiartha_elearning.pdf

Wihono, R. S. (2008, January 23). Meluruskan Salah Kaprah Tentang e-Learning. Diakses 27 Mei 2012, dari http://romisatriawahono.net/2008/01/23/meluruskan-salah-kaprah-tentang-elearning/ 